\title{
Nowe perspektywy leczenia przeciwzakrzepowego — środki hamujące czynnik krzepnięcia XI
}

\author{
New perspectives for antithrombotic therapy \\ - coagulation factor $\mathrm{XI}$ as a target
}

\author{
Jacek Treliński \\ Katedra i Klinika Hematologii, Uniwersytet Medyczny, Łódź
}

\begin{abstract}
Streszczenie
Ostatnie lata obfitowaty w wiele doniesień wskazujacych na kluczowa role czynnika krzepnięcia XI (fXI) w inicjowaniu i podtrzymywaniu procesów prowadzacych do rozwoju zakrzepicy. Wyniki badan eksperymentalnych na zwierzetach, a także wyniki badań I i II fazy z uzyciem antysensownych oligonukleotydów u ludzi wskazuja, ze zmniejszenie aktywności fXI prowadzi do korzystnego efektu przeciwzakrzepowego, bez jednoczesnego zwiększenia ryzyka krwawien. W pracy przedstawiono różne strategie postępowania prowadzace do zmniejszenia aktywności fXI. Omówiono także potencjalne ograniczenia zwiazane $z$ tq nowq metoda leczenia przeciwzakrzepowego.
\end{abstract}

Słowa kluczowe: leczenie przeciwzakrzepowe, czynnik krzepnięcia XI, przeciwciała monoklonalne, antysensowne oligonukleotydy

Hematologia 2015; 6, 3: 271-277

\begin{abstract}
In the recent years coagulation factor XI (fXI) has emerged as one of the main contributors to the pathogenesis of thrombosis. Results of the experimental studies, performed on animal models, as well as, results of phase I/II studies with $f X I$ antisense oligonucleotide in human, indicate, that selective fXI inhibition provides antithrombotic benefits without compromising the hemostasis. In paper, different modes of $f X I$ inhibition were described. Potential limitations of this novel antithrombotic therapy were also discussed.
\end{abstract}

Key words: antithrombotic therapy, coagulation factor XI, monoclonal antibodies, antisense oligonucleotides

Hematologia 2015; 6, 3: 271-277

\section{Wprowadzenie}

Powikłania zakrzepowe należą do głównych przyczyn śmiertelności w krajach wysoko uprzemysłowionych, a jednym $z$ podstawowych wyzwań leczenia przeciwzakrzepowego jest zachowanie równowagi między skutecznością terapii a ryzykiem rozwoju powikłań krwotocznych [1-4]. Niestety, zarówno klasyczne leki przeciwkrzepliwe (heparyny, antagoniści witaminy K), jak i zarejestrowane w ostatnich latach tak zwane nowe doustne leki przeciwkrzepliwe (bezpośrednie doustne inhibitory aktywnego czynnika X [fX, factor $X]$, bezpośrednie doustne inhibitory trombiny) charakteryzują się stosunkowo wysokim ryzykiem wystąpienia powikłań krwotocznych [5-8]. To zwiększone ryzyko krwawień wynika $z$ hamowania przez wymienione leki kluczowych dla procesów

Adres do korespondencji: Jacek Treliński, Katedra i Klinika Hematologii, Uniwersytet Medyczny, ul. Ciołkowskiego 2, 93-510 Łódź, tel. 4268950 58, faks 4268951 92, e-mail: jacek.trelinski@umed.lodz.pl 
hemostazy czynników krzepnięcia, takich jak: trombina, fXa czy protrombina. Dlatego wciąż poszukuje się nowych, efektywnych, a zarazem bezpiecznych sposobów leczenia przeciwzakrzepowego.

$Z$ jednej strony, jak wynika $z$ obserwacji klinicznych u ludzi, fXI nie jest tak istotny dla procesów hemostazy, jak na przykład fVIII i fIX, o czym świadczy między innymi fakt, że nawet znaczne zmniejszenie jego aktywności nie prowadzi zwykle do spontanicznych krwawień, jak w przypadku chorych na ciężką postać hemofilii A i B $[9,10]$. $Z$ drugiej strony, istnieją dowody wskazujące na istotny udział fXI w patogenezie zakrzepicy [11-19]. Ze względu na obie cechy fXI wydaje się dobrym celem terapeutycznym, a środki hamujące jego aktywność dają nadzieje na, tak oczekiwane, rozdzielenie efektu działania na zakrzep od wplywu na procesy fizjologicznej hemostazy, co może poprawić bezpieczeństwo i przynieść przełom w leczeniu przeciwzakrzepowym.

\section{Hamowanie fXI jako sposób profilaktyki i leczenia przeciwzakrzepowego - przesłanki teoretyczne}

Wyniki badań epidemiologicznych wskazują pośrednio na ważną rolę fXI w patogenezie powikłań zakrzepowych u ludzi. Jak wykazano $\mathrm{w}$ ostatnich latach, pacjenci $z$ ciężkim niedoborem fXI rzadziej chorują na udar niedokrwienny mózgu i żylną chorobę zakrzepowo-zatorową (VTE, venous thromboembolism) niż osoby z populacji ogólnej, natomiast podwyższona aktywność fXI wiąże się ze zwiększoną zapadalnością na zawał serca, udar niedokrwienny mózgu i VTE [16-18, 20-22]. Obserwacje te dobrze korelują $z$ wynikami badania
Leiden Thrombophilia Study, w którym aktywność fXI mieszcząca się w górnych $10 \%$ rozkładu normalnego wiązała się z 2 razy większą zapadalnością na VTE w odniesieniu do pozostałych uczestników badania [19].

U podstaw szerszego zainteresowania zagadnieniem hamowania aktywności fXI w kontekście leczenia przeciwzakrzepowego leżą wyniki testów przeprowadzonych na myszach pozbawionych genu dla fXI (KO, knock-out) [23]. Wykazano, $\dot{z} \mathrm{e} \mathrm{w}$ przeciwieństwie do myszy poddanych $\mathrm{KO}$ genów dla fIX, fX czy protrombiny, u których występowały objawy skazy krwotocznej bądź myszy te ginęły $z$ powodu krwawień, myszy pozbawione genu dla fXI nie doznawały nadmiernych krwawień, a ich czasy krwawienia były zbliżone do czasów krwawienia myszy niezmodyfikowanych genetycznie [23]. Stwierdzono także, że myszy pozbawione genu dla fXI są niezwykle odporne na rozwój zakrzepicy indukowanej eksperymentalnie, a jednocześnie nie krwawią nadmiernie, nawet po procedurach inwazyjnych [24, 25]. Dla porównania, myszy pozbawione genu dla fIX reagują podobnie w przypadku doświadczalnej zakrzepicy, ale wykrwawiają się na śmierć po chirurgicznym usunięciu końcówki ogona [25].

Kolejnym etapem badań były próby opracowania metod prowadzących do obniżenia aktywności fXI i zawartości antygenu fXI w celu uzyskania odpowiedniego efektu przeciwzakrzepowego przy jednoczesnym braku zwiększenia ryzyka krwawień. W tabeli 1 przedstawiono strategie hamowania fXI/fXIa, a w tabeli 2 - potencjalne zalety i wady poszczególnych środków hamujących, dotyczące między innymi sposobu podawania, czasu działania, ewentualnych wskazań, metod odwracania efektu przeciwkrzepliwego, a także oczekiwanych kosztów rynkowych.

Tabela 1. Wybrane środki hamujące czynnika XI/XIa (fXI/Xla) w badaniach klinicznych (źródło [15])

Table 1. Selected compounds used in clinical trials to achieve factor XI/Xla (fXI/Xla) inhibition (source [15])

\begin{tabular}{lll}
\hline Rodzaj środka & Badany środek & Mechanizm działania \\
\hline Antysensowne oligonukleotydy (ASO) & fXI-ASO & Zmniejszanie syntezy fXI \\
Przeciwciała monoklonalne & O1A6 (aXIMAb) & $\begin{array}{l}\text { Blokowanie aktywacji fXI } \\
\text { Blokowanie aktywacji fIX przez fXla } \\
\text { Blokowanie aktywacji fXI przez fXIla }\end{array}$ \\
& $14 \mathrm{E} 11$ & Nieodwracalne hamowanie miejsca aktywnego fXla \\
$\begin{array}{l}\text { Syntetyczne małe cząsteczki } \\
\text { Inhibitory miejsca aktywnego }\end{array}$ & $\begin{array}{l}\text { Pochodne kwasu } \\
\text { aryloboronowego }\end{array}$ & \\
BMS262084 & Siarczan pentagaloiloglukozy & Zmiana konformacji miejsca aktywnego fXI/Xla \\
Inhibitory allosteryczne & Clavatidine A, B & Nieodwracalne hamowanie miejsca aktywnego fXla \\
Naturalne inhibitory & Inhibitor miejsca aktywnego fXla
\end{tabular}


Tabela 2. Potencjalne zalety i wady wybranych sposobów hamowania czynnika XI/XIa ( $f X I / X I a)$

Table 2. Potential advantages and disadvantages of different ways to inhibit factor $\mathrm{XI} / \mathrm{fXla}(\mathrm{fXI} / \mathrm{Xla}$ )

\begin{tabular}{|c|c|c|c|c|c|}
\hline Rodzaj środka & $\begin{array}{c}\text { Sposób } \\
\text { podawania }\end{array}$ & $\begin{array}{l}\text { Początek/koniec } \\
\text { działania }\end{array}$ & $\begin{array}{c}\text { Rodzaj } \\
\text { wskazań }\end{array}$ & Antidotum & $\begin{array}{l}\text { Przewidywane } \\
\text { koszty rynkowe }\end{array}$ \\
\hline $\begin{array}{l}\text { Antysensowne } \\
\text { oligonukleotydy }\end{array}$ & $\begin{array}{c}\text { Dożylnie/podskórnie } \\
2 \times / \text { tydz. }\end{array}$ & Dni/dni & $\begin{array}{l}\text { Podostre, } \\
\text { przewlekłe }\end{array}$ & fXI & Wysokie \\
\hline $\begin{array}{l}\text { Przeciwciała } \\
\text { monoklonalne }\end{array}$ & $\begin{array}{l}\text { Dożylnie raz/ } \\
\text { /tydz./mies. }\end{array}$ & Min/tygodnie & $\begin{array}{c}\text { Ostre, } \\
\text { podostre, } \\
\text { przewlekłe }\end{array}$ & fXI & Wysokie \\
\hline $\begin{array}{l}\text { Niewielkie cząsteczki } \\
\text { (doustne) }\end{array}$ & $\begin{array}{l}\text { Doustnie } \\
2-4 \times / d \text {. }\end{array}$ & $\begin{array}{l}\text { Min-godziny/ } \\
\text { /godziny-dni }\end{array}$ & $\begin{array}{c}\text { Ostre, } \\
\text { podostre, } \\
\text { przewlekłe }\end{array}$ & $\begin{array}{c}\text { Czynniki krzepnięcia } \\
\text { poniżej fXI } \\
\text { w kaskadzie } \\
\text { krzepnięcia, } \\
\text { specyficzne inhibitory }\end{array}$ & Niskie \\
\hline $\begin{array}{l}\text { Niewielkie cząsteczki } \\
\text { (pozajelitowe) }\end{array}$ & Dożylnie/podskórnie & Min/min-godziny & $\begin{array}{c}\text { Ostre, } \\
\text { podostre }\end{array}$ & $\begin{array}{c}\text { Czynniki krzepnięcia } \\
\text { poniżej fXI } \\
\text { w kaskadzie } \\
\text { krzepnięcia, } \\
\text { specyficzne inhibitory }\end{array}$ & Umiarkowane \\
\hline
\end{tabular}

Należy podkreślić, że do tej pory jedynie metodę $z$ użyciem antysensownych oligonukleotydów (fXI-ASO, coagulation factor XI antisense oligonucleotides) zweryfikowano $\mathrm{w}$ badaniach klinicznych I/II fazy u ludzi. Pozostałe związki pozostają na etapie badań podstawowych lub są w fazie eksperymentów na zwierzętach.

\section{Antysensowne oligonukleotydy}

Zasada działania fXI-ASO polega na ich specyficznym wiązaniu się $\mathrm{w}$ wątrobie $\mathrm{z}$ mRNA (messenger RNA dla fXI). Utworzone $\mathrm{w}$ ten sposób, niefizjologiczne podwójne nici DNA/RNA indukują aktywność rybonukleazy histydynowej, co prowadzi do rozkładu wchodzących w ich skład cząsteczek mRNA. W konsekwencji dochodzi do zaburzenia procesów transkrypcji i translacji, obniżenia ekspresji genu dla fXI i zmniejszonej syntezy tego białka w wątrobie [26]. Jak wykazano w badaniach na myszach, zastosowanie fXI-ASO w dawce $50 \mathrm{mg} / \mathrm{kg} \mathrm{mc}$. podskórnie (s.c., subcutaneous) 2 razy w tygodniu przez 3 tygodnie skutkuje ponad 90-procentową redukcją aktywności fXI i zawartości antygenu XI. Myszy będące przedmiotem tego eksperymentu były tak samo odporne na wywoływaną doświadczalnie zakrzepicę jak myszy leczone warfaryną czy heparyną, przy czym najlepsze efekty uzyskiwano, gdy aktywność fXI zmniejszała się do wartości mniejszej lub równej $20 \%$ wartości prawidłowych [27]. Stwierdzono także, że króliki leczone fXI-ASO są całkowicie odporne na zakrzepicę indukowaną cewnikiem naczyniowym [28].
W 2011 roku przedstawiono wyniki badania I fazy u ludzi z udziałem zdrowych ochotników [29]. Po zastosowaniu fXI-ASO (ISIS-fXIRx) w dawkach $200 \mathrm{mg}$ lub $300 \mathrm{mg}$ s.c., powtarzanych 2 razy w tygodniu, regularnie uzyskiwano zmniejszenie stężenia antygenu i aktywności fXI o około $80 \%$, a w niektórych przypadkach redukcja ta przekraczała 95\%. Jednocześnie nie obserwowano poważnych działań niepożądanych, a zwłaszcza pojawienia się powikłań krwotocznych. Do najczęściej występujących skutków niepożądanych należały podrażnienie skóry, a także odczyny zapalne w miejscu wstrzyknięć fXI-ASO. Zachęcające efekty wymienionych prób klinicznych były podstawą do rozpoczęcia badania II fazy, którego wyniki opublikowano w 2014 roku [30]. Jego głównym celem było porównanie skuteczności i bezpieczeństwa fXI-ASO, stosowanych w dwóch dawkach (200 mg s.c. i $300 \mathrm{mg}$ s.c.), ze standardową dawką enoksaparyny (40 mg s.c.) w profilaktyce VTE $\mathrm{u}$ chorych poddanych zabiegowi alloplastyki stawu kolanowego. U wszystkich chorych 8-12 po zabiegu wykonywano obustronną wenografię. Antysensowne oligonukleotydy stosowano $\mathrm{w}$ postaci zastrzyków s.c., w dziewięciu dawkach, przy czym pierwszą dawkę podawano 36 dni przed zabiegiem, a ostatnie dwie dawki - w dniu operacji oraz 3 dni po zabiegu. Aktywność fXI w dniu zabiegu wynosiła $0,38 \pm 0,01 \mathrm{j} . / \mathrm{ml}, 0,20 \pm 0,01 \mathrm{j} / \mathrm{ml} \mathrm{i} 0,93 \pm 0,02 \mathrm{j} . / \mathrm{ml}$ $\mathrm{w}$ grupie chorych otrzymujących, odpowiednio, $200 \mathrm{mg}$ fXI-ASO, $300 \mathrm{mg}$ fXI-ASO i $40 \mathrm{mg}$ enoksaparyny (dla przypomnienia: prawidłowa aktywność fXI w osoczu to $0,5-1,5 \mathrm{j}$./ml). Zakrzepica żylna 
wystąpiła u $27 \%$ chorych (36 osób) otrzymujących $200 \mathrm{mg}$ fXI-ASO, $4 \%$ chorych (3 osoby) otrzymujących $300 \mathrm{mg}$ fXI-ASO oraz 30\% pacjentów (21 osób) leczonych enoksaparyną, natomiast powikłania krwotoczne dotyczyły w poszczególnych grupach, odpowiednio, 3\%, 3\% i $8 \%$ pacjentów. Statystycznie dawka $200 \mathrm{mg}$ fXI-ASO okazała się nie gorsza, a dawka $300 \mathrm{mg}$ fXI-ASO - lepsza $(\mathrm{p}<0,001)$ od standardowej dawki enoksaparyny w zapobieganiu zakrzepicy żylnej w badanej sytuacji klinicznej. Należy podkreślić, że tak wysokiej skuteczności fXI-ASO towarzyszyło niższe niż w przypadku enoksaparyny ryzyko krwawień.

Choć niezwykle obiecujące, wyniki te muszą być jeszcze potwierdzone $\mathrm{w}$ większych grupach chorych. Sprawdzenia wymaga zwłaszcza fakt wykazania mniejszego w odniesieniu do stosowania fXI-ASO odsetka powikłań krwotocznych [31, 32]. Dyskusyjny w pracy Büllera i wsp. [30] jest także sposób oceny odsetka powikłań zakrzepowych - tj. poprzez włączenie przypadków zakrzepicy dystalnej niemej klinicznie. Ten rodzaj zakrzepicy w warunkach pooperacyjnych jest zjawiskiem stosunkowo częstym i może w ogóle nie mieć znaczenia klinicznego. Nie ulega natomiast wątpliwości, że przedstawione wyniki rzucają nowe światło na patogenezę zakrzepicy żylnej związanej $z$ zabiegiem operacyjnym, uwydatniając rolę fXI, a odsuwając niejako na dalszy plan rolę czynnika tkankowego i zewnątrzpochodnej drogi krzepnięcia.

\section{Przeciwciala monoklonalne skierowane przeciw fXI/fXIa}

Przeciwciała monoklonalne stanowią obecnie jedną $z$ najważniejszych grup leków wykorzystywanych w onkologii i hematologii. Zainteresowanie przeciwciałami inhibitorowymi skierowanymi do fXI zwiększyło się po opublikowaniu pracy, w której zaobserwowano, że zastosowanie poliklonalnych przeciwciał skierowanych przeciw ludzkiemu fXI u pawianów skutkuje całkowitą opornością na rozwój zakrzepicy wywoływanej wszczepianiem zwierzętom protez naczyniowych [33]. Do najlepiej przebadanych należą IgG 01A6 (aXIMab) i IgG 14E11 [11, 24, 34].

Przeciwciało monoklonalne IgG 01A6 (aXIMab) jest wytwarzane poprzez immunizację myszy, niemodyfikowanych genetycznie, ludzkim fXI $[11,34]$. Przeciwciało aXIMab hamuje aktywację fIX przez fXIa, blokując miejsce wiążące fIX na domenie A3 fXIa [34, 35]. U pawianów podanie aXIMab s.c. w pojedynczej dawce $2 \mathrm{mg} / \mathrm{kg} \mathrm{mc}$. w czasie
10 dni od momentu wstrzyknięcia powoduje spadek aktywności fXI do wartości prawie nieoznaczalnych, a jednocześnie $\mathrm{w}$ okresie tym obserwuje się stopniowy wzrost stężenia fXI. Wskazuje to na zahamowanie aktywacji, a nie zwiększony klirens osoczowy fXI, jako główny mechanizm działania tego przeciwciała [11]. Stwierdzono także, że w obecności aXIMab dochodzi do znacząco mniejszego, w stosunku do placebo i kwasu acetylosalicylowego, odkładania się płytek krwi i fibryny wewnątrz pokrytych od środka warstwą kolagenu, wszczepianych doświadczalnie protez naczyniowych [11]. Tworzące się w obecności aXIMab agregaty płytkowe były mniejsze i bardziej niestabilne niz $\mathrm{w}$ grupie kontrolnej, a procesy prowadzące do generacji trombiny wewnątrz protezy - znacznie osłabione, o czym świadczy o ponad $80 \%$ mniejsze odkładanie się fibryny w stosunku do grupy kontrolnej. Natomiast, w przeciwieństwie do kwasu acetylosalicylowego, aXIMab nie powodował przedłużenia czasu krwawienia.

$Z$ kolei przeciwciało IgG 14E11 jest wytwarzane poprzez immunizację myszy pozbawionych genu dla fXI mysim fXI [24]. Przeciwciało to wiąże się $z$ domeną A2 fXI/fXIa wielu gatunków, w tym ludzi, blokując $\mathrm{w}$ warunkach in vitro aktywację fXI przez fXIIa. Przeciwciało 14E11 nie blokuje natomiast aktywacji fXI przez trombinę ani fIX przez aktywny fXI. W opisanym wyżej układzie badawczym $z$ użyciem wszczepionej protezy naczyniowej podanie 14E11 skutkowało znacząco mniejszym (w stosunku do grupy kontrolnej) odkładaniem się w świetle protezy naczyniowej fibryny, natomiast nie stwierdzono różnic w zakresie odkładania się płytek krwi.

\section{Syntetyczne małe cząsteczki hamujące miejsce aktywne fXIa}

Mimo licznych prób dotychczas opracowano tylko kilka cząsteczek charakteryzujących się wystarczająco wysoką swoistością względem fXIa w stosunku do innych białek krzepnięcia i fibrynolizy. W 2006 roku stwierdzono, że kwas aryloborowy zastosowany w stężeniu około $1400 \mathrm{nM}$, powoduje spadek aktywności fXI o około 50\%, wykazując jednocześnie, odpowiednio, 8-krotnie i 20-krotnie mniejszą swoistość względem trombiny i fXa [36]. Innym inhibitorem nieodwracalnie hamującym miejsce aktywne fXIa jest związek BMS262084 [37]. Środek ten wywołuje zależny od dawki efekt antykoagulacyjny na modelu zakrzepicy tętniczej i żylnej u królików. Użyty w stężeniu $0,8 \mu \mathrm{M}$ powoduje dwukrotne wydłużenie czasu częściowej tromboplastyny po aktywacji (aPTT, 
activated partial thromboplastin time) ludzkiego osocza, nie wpływając jednocześnie na aktywność i stężenie pozostałych czynników krzepnięcia ani na parametry czynnościowe płytek krwi.

\section{Syntetyczne allosteryczne inhibitory fXIa}

Według definicji encyklopedycznej inhibicja allosteryczna to obniżenie aktywności katalitycznej enzymu w wyniku zmiany jego konformacji spowodowanej przyłączeniem się inhibitora do miejsca innego niż miejsce aktywne. Dokładnie taki mechanizm działania charakteryzuje siarczan pentagaloiloglukozy (SPGG, sulfated pentagalloylglucoside) [38]. Jako związek ujemnie naładowany SPGG łączy się $z$ dodatnio naładowanymi resztami aminokwasów w domenie katalitycznej fXIa, stanowiącymi miejsce wiązania heparyny. Powoduje to szereg reakcji chemicznych zmieniających konformację miejsca aktywnego enzymu i skutkuje hamowaniem aktywacji fIX przez fXIa już w stężeniach submikromolarnych [39, 40]. Cząsteczka ta wykazuje przy tym około 200 razy większą swoistość względem fXIa niż inne czynniki krzepnięcia [41].

\section{Naturalnie występujące inhibitory fXIa}

Do naturalnie występujących inhibitorów fXIa należą Clavatidine A i B oraz Desmolaris. Clavatidine $\mathrm{A}$ i B to zawierające brom nieodwracalne inhibitory miejsca aktywnego fXIa $\left(\mathrm{IC}_{50}\right.$ odpowiednio $1,3 \mu \mathrm{M}$ i $27 \mu \mathrm{M}$ ) wyizolowane $z$ gatunku gąbki morskiej Suberea clavata [42]. Z kolei Desmolaris pochodzi ze śliny nietoperza $z$ podrodziny wampirowatych (Desmodus rotundus) [43] i jest związkiem homologicznym do inhibitora zewnątrzpochodnej drogi krzepnięcia (TFPI, tissue factor pathway inhibitor). Podobnie jak TFPI jest zbudowany $z$ tak zwanych domen Kunitza. Jedna $z$ takich domen, po połączeniu $z$ miejscem aktywnym fXIa, powoduje jego zablokowanie. Podawany myszom w dawce $100 \mu \mathrm{g} / \mathrm{kg} \mathrm{mc}$. Desmolaris zapobiegał powstawaniu skrzepliny na modelu zakrzepicy tętniczej wywoływanej chlorkiem żelaza, bez jednoczesnego przedłużenia czasu krwawienia [43].

\section{Potencjalne wskazania i ograniczenia dotyczące środków \\ hamujących aktywność/stężenie fXI}

Potencjalne wskazania dla nowych leków hamujących aktywność/stężenie fXI są bardzo szerokie. Obejmują one pierwotną lub wtórną profilaktykę VTE i udarów niedokrwiennych mózgu, ale przede wszystkim te stany kliniczne wymagające antykoagulacji, w których istnieją przeciwwskazania do zastosowania obecnie dostępnych leków przeciwzakrzepowych. Można zakładać, że ze względu na wybitnie wzmożoną aktywację układu wewnątrzpochodnego krzepnięcia szczególne korzyści odniosą chorzy $z$ wszczepionymi sztucznymi powierzchniami (protezy naczyniowe, zastawki mechaniczne), a także pacjenci poddawani procedurze krążenia pozaustrojowego. Nie można wykluczyć, że środki hamujące fXI znajdą także zastosowanie $\mathrm{w}$ leczeniu skojarzonym, wspólnie $z$ obecnie znanymi antykoagulantami (np. w profilaktyce udarów niedokrwiennych mózgu u chorych $z$ migotaniem przedsionków) czy lekami przeciwpłytkowymi (w chorobie wieńcowej czy miażdżycy zarostowej tętnic), co pozwoli na poprawę wyników leczenia tych chorób, przy jednoczesnym obniżeniu ryzyka wystąpienia powikłań krwotocznych, na przykład dzięki zmniejszeniu dawek leków tradycyjnych.

Należy podkreślić, że badania dotyczące środków hamujących fXI są na wczesnym etapie, a ich korzystne wyniki muszą być jeszcze potwierdzone $\mathrm{w}$ znacznie większych grupach chorych. Nie wiadomo, czy środki hamujące fXI cechuje wystarczający potencjał terapeutyczny, by znalazły zastosowanie w leczeniu ostrych incydentów zakrzepowych. W niektórych przypadkach (np. fXI-ASO) leczenie takie nie jest możliwe $z$ powodu długiego czasu, który upływa od momentu pierwszego podania do pojawienia się pożądanego efektu przeciwzakrzepowego. Część badaczy zaleca ostrożność przy próbach stosowania nowych leków w sytuacjach klinicznych związanych $z$ dużym pobudzeniem fibrynolizy (np. operacja prostaty, zabiegi w obrębie jamy ustnej). Istotnymi przeszkodami w upowszechnieniu konkretnych leków mogą być także niewygodny sposób podawania, koszty wytwarzania oraz brak specyficznego antidotum.

\section{Podsumowanie}

Dotychczasowe wyniki badań wskazują, że zmniejszenie aktywności/stężenia fXI jest interesującym celem terapii przeciwzakrzepowej, dając nadzieję na odpowiednio wysoką skuteczność, a zarazem zwiększone bezpieczeństwo leczenia. Potencjalne wskazania do stosowania nowych leków są bardzo szerokie i obejmują pierwotną i wtórną profilaktykę zakrzepicy żylnej i tętniczej, a także stany kliniczne wymagające antykoagulacji, w których istnieją przeciwwskazania do podawania 
obecnie dostępnych leków przeciwzakrzepowych. Ostateczna odpowiedź na pytanie o zasadność tego sposobu postępowania przeciwzakrzepowego będzie jednak znana dopiero po przeprowadzeniu badań w dużych grupach chorych i w różnych wskazaniach klinicznych.

\section{Piśmiennictwo}

1. Centers for Disease Control and Prevention (CDC). Venous thromboembolism in adult hospitalizations - United States, 2007-2009. MMWR Morb. Mortal. Wkly. Rep. 2012; 61: 401-404.

2. Cushman M., Tsai A.W., White R.H. i wsp. Deep vein thrombosis and pulmonary embolism in two cohorts: the longitudinal investigation of thromboembolism etiology. Am. J. Med. 2004; 117: $19-25$.

3. Heit J.A. The epidemiology of venous thromboembolism in the community: implications for prevention and management. J. Thromb. Thrombolysis 2006; 21: 23-29.

4. Zawilska K., Bała M.M., Błędowski P. i wsp. Polish guidelines for the prevention and treatment of venous thromboembolism. 2012 update. Pol. Arch. Med. Wewn. 2012; 122, 2: 3-74.

5. Weitz J.I. New oral anticoagulants: a view from the laboratory. Am. J. Hematol. 2012; 87, 1: 133-136.

6. Broussalis E., Anna W., Trinka E., Mutzenbach S., Killer M. Latest developments in anticoagulant drug discovery. Drug Discov. Today 2014; 19: 921-935.

7. Werth S., Breslin T., NiAinle F., Beyer-Westendorf J. Bleeding risk, management and outcome in patients receiving non-VKA oral anticoagulants (NOACs). Am. J. Cardiovasc. Drugs 2015; 15: 235-242.

8. van der Hulle T., Kooiman J., den Exter P.L. i wsp. Effectiveness and safety of novel oral anticoagulants as compared with vitamin $\mathrm{K}$ antagonists in the treatment of acute symptomatic venous thromboembolism: a systematic review and meta-analysis. J. Thromb. Haemost. 2014; 12: 320-328.

9. Duga S., Salomon O. Congenital Factor XI deficiency: an update. Semin. Thromb. Hemost. 2013; 39: 621-631.

10. Zawilska K., Chojnowski K., Klukowska A. i wsp. Polskie zalecenia postępowania w rzadkich niedoborach osoczowych czynników krzepnięcia. Hematologia 2011; 2: 303-310.

11. Tucker E.I., Marzec U.M., White T.C. i wsp. Prevention of vascular graft occlusion and thrombus-associated thrombin generation by inhibition of factor XI. Blood 2009; 113: 936-944.

12. Löwenberg E.C., Meijers J.C., Monia B.P., Levi M. Coagulation factor XI as a novel target for antithrombotic treatment. J. Thromb. Haemost. 2010; 8: 2349-2357.

13. van Montfoort M.L., Meijers J.C. Anticoagulation beyond direct thrombin and factor Xa inhibitors: indications for targeting the intrinsic pathway? Thromb. Haemost. 2013; 110: 223-232.

14. van Montfoort M.L., Knaup V.L., Marquart J.A. i wsp. Two novel inhibitory anti-human factor XI antibodies prevent cessation of blood flow in a murine venous thrombosis model. Thromb. Haemost. 2013; 110: 1065-1073.

15. Gailani D. Future prospects for contact factors as therapeutic targets. Hematology Am. Soc. Hematol. Educ. Program 2014: 52-59.

16. Cushman M., O'Meara E.S., Folsom A.R., Heckbert S.R. Coagulation factors IX through XIII and the risk of future venous thrombosis: the Longitudinal Investigation of Thromboembolism Etiology. Blood 2009; 114: 2878-2883.
17. Doggen C.J., Rosendaal F.R., Meijers J.C. Levels of intrinsic coagulation factors and the risk of myocardial infarction among men: opposite and synergistic effects of factors XI and XII. Blood 2006; 108: 4045-4051.

18. Yang D.T., Flanders M.M., Kim H., Rodgers G.M. Elevated factor XI activity levels are associated with an increased odds ratio for cerebrovascular events. Am. J. Clin. Pathol. 2006; 126: 411-415 .

19. Meijers J.C., Tekelenburg W.L., Bouma B.N., Bertina R.M., Rosendaal F.R. High levels of coagulation factor XI as a risk factor for venous thrombosis. N. Engl. J. Med. 2000: 342: 696-701.

20. Salomon O., Steinberg D.M., Zucker M. i wsp. U. Patients with severe factor XI deficiency have a reduced incidence of deep-vein thrombosis. Thromb. Haemost. 2011; 105: 269-273.

21. Salomon O., Steinberg D.M., Koren-Morag N., Tanne D., Seligsohn U. Reduced incidence of ischemic stroke in patients with severe factor XI deficiency. Blood 2008; 111: 4113-4117.

22. Siegerink B., Govers-Riemslag J.W., Rosendaal F.R., Ten Cate H., Algra A. Intrinsic coagulation activation and the risk of arterial thrombosis in young women: results from the Risk of Arterial Thrombosis in relation to Oral contraceptives (RATIO) case-control study. Circulation 2010; 122: 1854-1861.

23. Gailani D., Lasky N.M., Broze G.J. Jr. A murine model of factor XI deficiency. Blood Coagul. Fibrinol. 1997; 8: 134-144.

24. Cheng Q., Tucker E.I., Pine M.S. i wsp. A role for factor XIIa-mediated factor XI activation in thrombus formation in vivo. Blood 2010; 116: 3981-3989.

25. Wang X., Cheng Q., Xu L. i wsp. Effects of factor IX or factor XI deficiency on ferric chlorideinduced carotid artery occlusion in mice. J. Thromb. Haemost. 2005; 3: 695-702.

26. Zhang H., Löwenberg E.C., Crosby J.R. i wsp. Inhibition of the intrinsic coagulation pathway factor XI by antisense oligonucleotides: a novel antithrombotic strategy with lowered bleeding risk. Blood 2010; 116: 4684-4692.

27. Crosby J.R., Marzec U., Revenko A.S. i wsp. Antithrombotic effect of antisense factor XI oligonucleotide treatment in primates. Arterioscler. Thromb. Vasc. Biol. 2013; 33: 1670-1678.

28. Yau J.W., Liao P., Fredenburgh J.C. i wsp. Selective depletion of factor XI or factor XII with antisense oligonucleotides attenuates catheter thrombosis in rabbits. Blood 2014; 123: 2102-2107.

29. Liu Q., Bethune C., Dessouki E. i wsp. ISIS-FXIRx, a novel and specific antisense inhibitor of factor XI, caused significant reduction in FXI antigen and activity and increased aPTT without causing bleeding in healthy volunteers. Blood 2011; 118: abstrakt 209.

30. Büller H.R., Bethune C., Bhanot S. i wsp. Factor XI antisense oligonucleotide for prevention of venous thrombosis. N. Engl. J. Med. 2015; 372: 232-240.

31. Flaumenhaft R. Making (anti)sense of factor XI in thrombosis. N. Engl. J. Med. 2015; 372: 277-278.

32. Gupta A. Factor XI antisense oligonucleotide for venous thrombosis. N. Engl. J. Med. 2015; 372: 1671.

33. Gruber A., Hanson S.R. Factor XI-dependence of surface- and tissue factor-initiated thrombus propagation in primates. Blood 2003; 102: 953-955.

34. Geng Y., Verhamme I.M., Messer A. i wsp. A sequential mechanism for exosite-mediated factor IX activation by factor XIa. J. Biol. Chem. 2012; 287: 38200-38209.

35. Geng Y., Verhamme I.M., Sun M.F. i wsp. Analysis of the factor XI variant Arg184Gly suggests a structural basis for factor IX binding to factor XIa. J. Thromb. Haemost. 2013; 11: 1374-1384. 
36. Lazarova T.I., Jin L., Rynkiewicz M. i wsp. Synthesis and in vitro biological evaluation of aryl boronic acids as potential inhibitors of factor XIa. Bioorg. Med. Chem. Lett. 2006; 16: 5022-5027.

37. Wong P.C., Crain E.J., Watson C.A., Schumacher W.A. A small-molecule factor XIa inhibitor produces antithrombotic efficacy with minimal bleeding time prolongation in rabbits. J. Thromb. Thrombolysis 2011; 32: 129-137.

38. Quan M.L., Wong P.C., Wang C. i wsp. Tetrahydroquinoline derivatives as potent and selective factor XIa inhibitors. J. Med. Chem. 2014; 57: 955-969.

39. Karuturi R., Al-Horani R.A., Mehta S.C., Gailani D., Desai U.R. Discovery of allosteric modulators of factor XIa by targeting hydrophobic domains adjacent to its heparin-binding site. J. Med. Chem. 2013; 56: 2415-2428.
40. Geng Y., Verhamme I.M., Smith S.A. i wsp. factor XI anion-binding sites are required for productive interactions with polyphosphate. J. Thromb. Haemost. 2013; 11: 2020-2028.

41. Al-Horani R.A., Ponnusamy P., Mehta A.Y., Gailani D., Desai U.R. Sulfated pentagalloylglucoside is a potent, allosteric, and selective inhibitor of factor XIa. J. Med. Chem. 2013; 56: 867-878.

42. Buchanan M.S., Carroll A.R., Wessling D. i wsp. Clavatadine A, a natural product with selective recognition and irreversible inhibition of factor XIa. J. Med. Chem. 2008; 51: 3583-3587 .

43. Ma D., Mizurini D.M., Assumpção T.C. i wsp. Desmolaris, a novel factor XIa anticoagulant from the salivary gland of the vampire bat (Desmodus rotundus) inhibits inflammation and thrombosis in vivo. Blood 2013; 122: 4094-4106. 